University of Nebraska - Lincoln

DigitalCommons@University of Nebraska - Lincoln

1988

Comparative Notes on the Biology and Development of Epeolus compactus Cresson., a Cleptoparasite of Colletes kincaidii Cockerell (Hymenoptera: Anthophoridae, Colletidae)

\author{
P. F. Torchio \\ USDA-ARS \\ D. J. Burdick \\ USDA-ARS
}

Follow this and additional works at: https://digitalcommons.unl.edu/entomologyother

Part of the Entomology Commons

Torchio, P. F. and Burdick, D. J., "Comparative Notes on the Biology and Development of Epeolus compactus Cresson., a Cleptoparasite of Colletes kincaidii Cockerell (Hymenoptera: Anthophoridae, Colletidae)" (1988). Entomology Papers from Other Sources. 61.

https://digitalcommons.unl.edu/entomologyother/61

This Article is brought to you for free and open access by the Entomology Collections, Miscellaneous at DigitalCommons@University of Nebraska - Lincoln. It has been accepted for inclusion in Entomology Papers from Other Sources by an authorized administrator of DigitalCommons@University of Nebraska - Lincoln. 


\title{
Comparative Notes on the Biology and Development of Epeolus compactus Cresson, a Cleptoparasite of Colletes kincaidii Cockerell (Hymenoptera: Anthophoridae, Colletidae)
}

\author{
P. F. TORCHIO AND D. J. BURDICK ${ }^{1}$
}

USDA-ARS, Bee Biology and Systematics Laboratory, Utah State University, Logan, Utah 84322

Ann. Entomol. Soc. Am. 81(4): 626-636 (1988)

\begin{abstract}
The biology of the nomadine bee, Epeolus compactus Cresson, is described based on composite notes taken from field, laboratory, and greenhouse studies of the host bee, Colletes kincaidii Cockerell. Details of Epeolus egg deposition are described and compared with other known nomadine bees. We document the release of a glandular secretion during egg deposition by $E$. compactus which dissolves the polyester host cell lining on contact. Late embryogenesis and hatching of Epeolus are described and adaptive features are discussed. The cleptoparasitic habits of the first instar are outlined, and anatomical differences expressed by various instars are compared. Methods used by Epeolus in parasitizing host nests excavated by the nesting Colletes female, or in host nests constructed in existing burrows, are reported. Possible reasons why rates of parasitism differ between kinds of nest architectures constructed by the host bee are discussed in some detail. Potentially useful biosystematic characters of immature stages of Epeolus are compared with those of other known nomadine bees.
\end{abstract}

KEY WORDS Insecta, Epeolus, biology, coevolution

Epeolus IS A holarctic genus of nomadine bees that is cleptoparasitic on Colletes. Hurd (in Krombein et al. 1979) lists 50 species in America north of Mexico, and Brumley (1965) recognized an additional seven species from the western United States. Of this total, eight Epeolus species are tentatively associated with their Colletes hosts in the New World (Krombein et al. 1979). However, the immature stages of only one species, Epeolus pusillus Cresson, are known, and they have been recovered from cells of three hosts-Colletes ciliatoides Stephen (Torchio 1965), Colletes deserticola Timberlake (G. E. Bohart in Rozen 1966); and Colletes compactus compactus Cresson (Rozen \& Favreau 1968). Another nomadine genus, Isepeolus, replaces Epeolus in South America as a parasite of Colletes (Claude-Joseph 1926, Michener 1957).

Although Epeolus is a widely distributed, speciesrich genus, its biology is known from only one study (Rozen \& Favreau 1968). These authors report egg deposition and development of immature forms of E. pusillus in nests of C. compactus compactus. This Colletes and the other host species of E. pusillus whose biology is known, C. ciliatoides (Torchio 1965), construct a single cell at the terminus of each lateral burrow. Our study describes some biological features of Epeolus compactus Cresson that attacks Colletes kincaidii Cockerell. This host

${ }^{1}$ Department of Biology, California State University, Fresno, Calif. 93710 species constructs linear series of interconnected cells in lateral burrows. This study presents new information on egg structure, egg deposition, embryogenesis, immature development, and rates of parasitism for $E$. compactus.

\section{Materials and Methods}

The host nest site was located at Bonny Doon, Santa Cruz County, Calif., where C. kincaidii nested gregariously in several of the hard-cased sandstone cliffs that interrupt a primarily flat terrain (Torchio et al. 1988). Two large sandstone blocks containing live nests of $C$. kincaidii were removed from one of the cliffs in March 1985 and transported to the USDA-ARS laboratory in Logan, Utah, where 46 host immatures and one Epeolus prepupa were recovered from one of the sandstone blocks.

The Bonny Doon site was revisited on 5-6 July 1985 during peak nesting activities, and numerous nests were dissected from a second sandstone cliff $600 \mathrm{~m}$ from where the first sandstone blocks were removed. During these excavations, eggs, young larvae, and a few prepupae of E. compactus were uncovered. Eggs were immersed in paraffin oil, and larvae were placed in artificial cells (clay blocks, each with a drilled hole lined with paraffin). All materials were stored in a Styrofoam container supplied with a commercial coolant. The container was transported from Bonny Doon to the USDA laboratory by vehicle on 6-8 July 1985, where we 

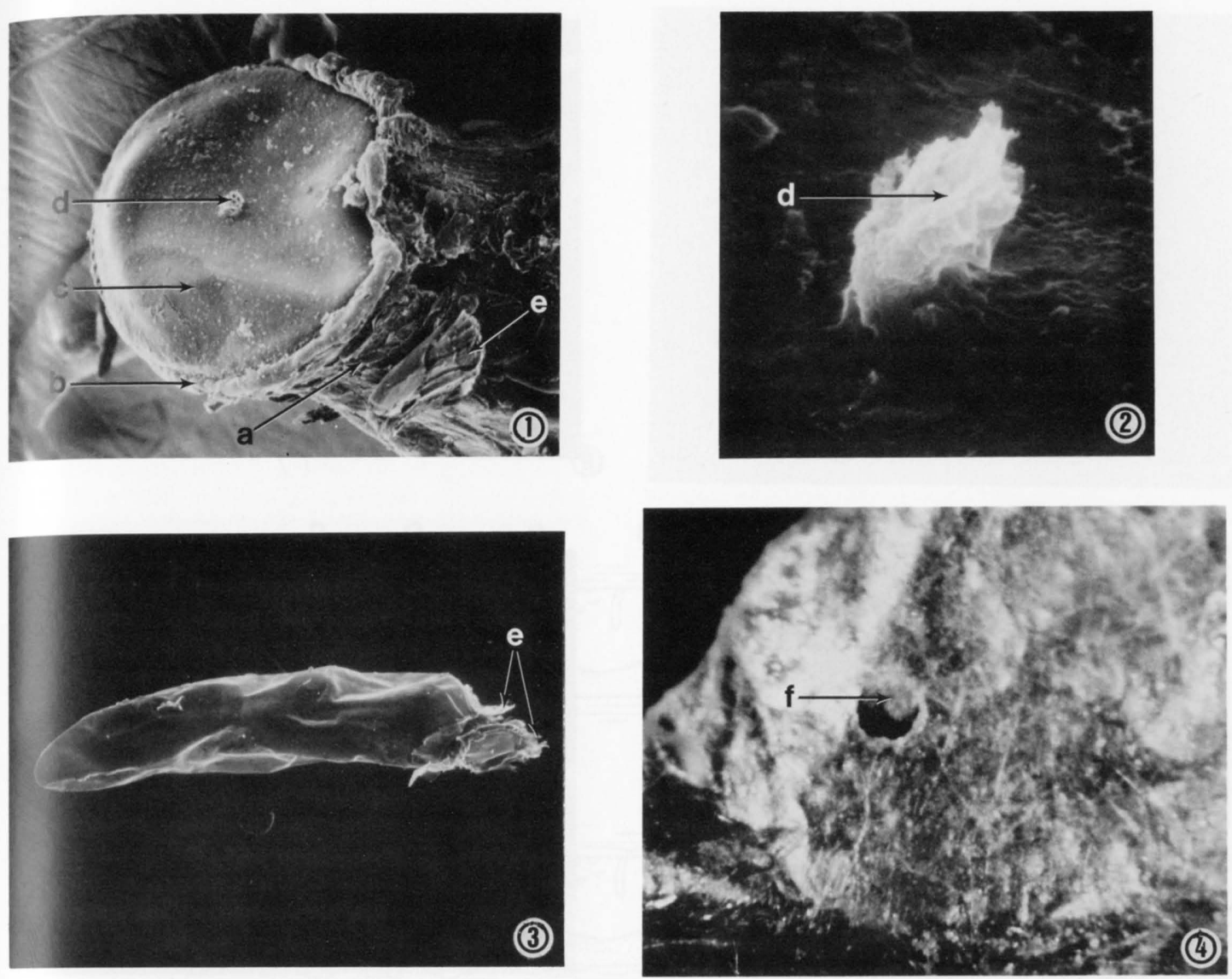

Fig. 1-4. E. compactus. (1) Anterior section of egg with flange, operculum, and neck region in view. (2) Central area of operculum showing structure of interfollicular tissue. (3) Lateral view of partially collapsed egg showing angulation of flattened anterior tip, operculum-flange, and host cell lining attached to neck and flange regions. (4) Circular hole cut through basal section of host cell lining preparatory to insertion of egg into hole. (a, neck region; b, flange; c, operculum; d, residue of interfollicular tissue attached to operculum; e, part of cell lining layer melded to egg; $f$, a flap of host cell lining that is pushed inward during period that parasite cuts hole through a section of polyester lining preparatory to egg deposition.)

completed the observations. Several blocks of sandstone were also removed from the nesting site and transported to Utah at the same time.

Observations of the Epeolus material were initiated at Bonny Doon, continued periodically during transport between states, and completed under laboratory conditions in Utah. These notes have been combined into the following composite description of the biology of E. compactus. All Epeolus materials recovered in this study have been deposited in the USDA-ARS collection, Bee Biology and Systematics Laboratory, Logan, Utah.

\section{Results}

A total of 250 C. kincaidii cells constructed during the 1985 nesting season was excavated and examined with the aid of a dissecting microscope at the Bonny Doon site on 5-6 July 1985. Of that total, 44 cells (17.6\%) were parasitized by E. com- pactus (21 cells with eggs, 16 with first-instar larvae, 3 with young larvae, and 4 with prepupae). The majority of these immatures died during transit from California to Utah. The transported soil blocks were dissected on 9 July 1985, and 44 eggs or young larvae of Colletes and two live Epeolus immatures (one egg and one first-instar larva) were obtained. These eggs were placed in paraffin oil preparatory to in vivo observations of late embryogenesis. The live Epeolus larva was reared (in situ) in the laboratory.

Egg Structure. Eggs of E. compactus were small (1.3-1.7 mm long, 0.22 $\mathrm{mm}$ maximum diameter, 20 measurements), circular in cross section, opaque white, and highly reflective when first deposited. These curved, elongated eggs each had a flattened anterior tip with a narrow but distinguishable flange surrounding a large diameter operculum (Fig. 1) ornamented centrally with a distinctive elevation (Fig. 1 and 2) (probably residue of interfollicular 

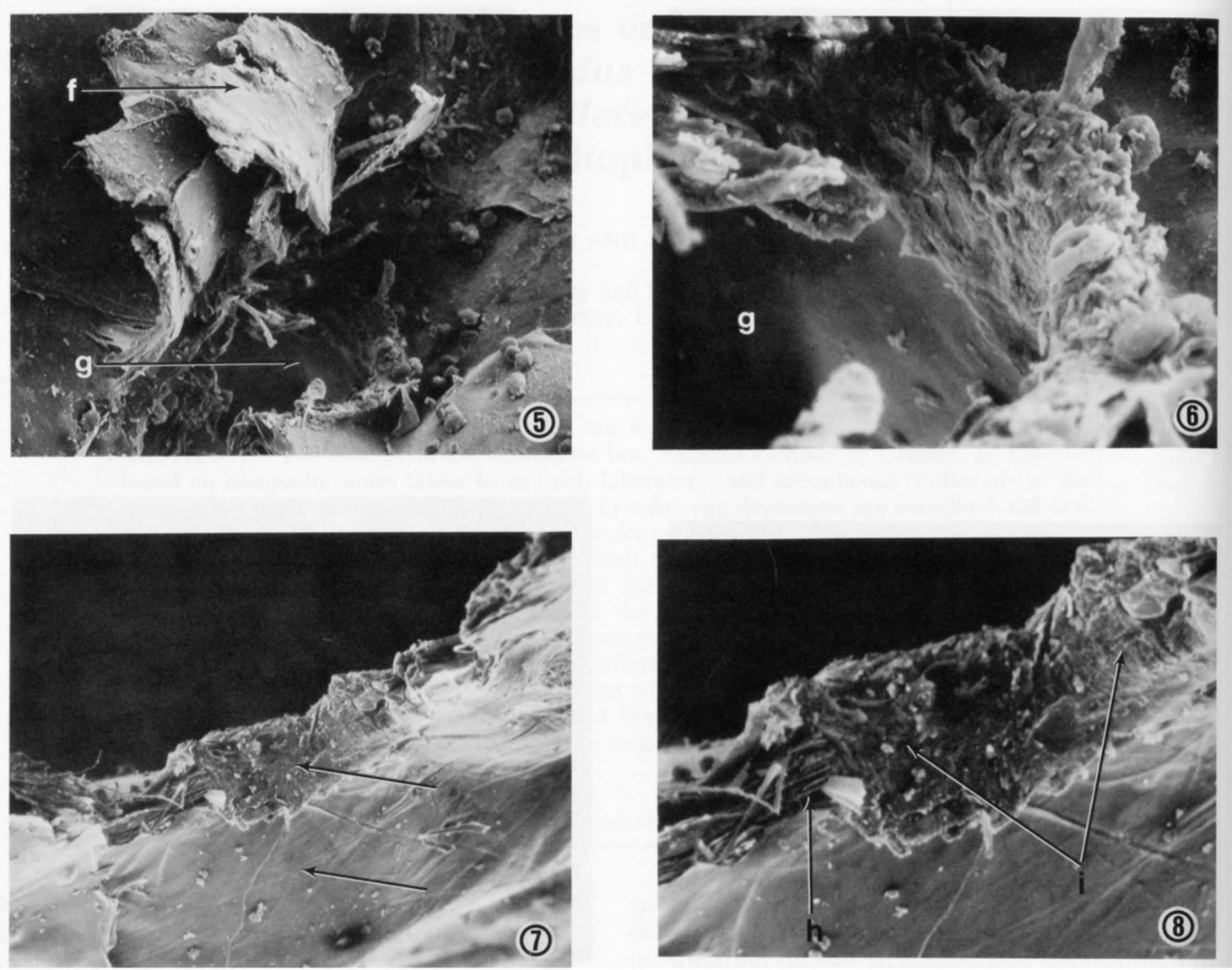

Fig. 5-8. C. kincaidii. (5) Inner surface of cell cap with hole cut by female $E$. compactus and flap of cell lining attached to one side of cut hole. (6) Edge of hole cut through cell lining by E. compactus showing that laminated layers of polyester have been dissolved and resolidified. (7) A different section of the edge of cut hole shown in Fig. 5 and 6 with upper arrow ending at dissolved and resolidified surface and lower arrow pointing to inner surface of polyester cell lining. (8) A magnified view of Fig. 7 showing laminations of undissolved cell lining adjacent to the dissolved and resolidified section of cell lining around edge of hole cut by a female $E$. compactus from which egg has been removed. $(\mathrm{f}$, a flap of host cell lining that is pushed inward during period that parasite cuts hole through a section of polyester lining preparatory to egg deposition; g, hole in cell cap cut by a female $E$. compactus; $\mathrm{h}$, laminated layers of polyester which, together, form the cell lining; $\mathrm{i}$, section of cell lining forming edge of cut hole showing results of the dissolving and resolidification process that occurs when E. compactus secretes enzymatic liquids onto laminated layers of host cell lining during egg deposition.)

tissue). The egg was narrowed into a neck region immediately behind the slanting but flattened anterior tip (Fig. 3 and 9), and its posterior tip was narrowly rounded. The entire egg chorion was without reticulations, and it was thicker and less pliable than the egg chorion of its Colletes host.

Egg Deposition. Upon entering unsealed host cells, females of $E$. compactus cut holes in the polyester lining (Fig. 4) (methodology described below) and inserted an egg through each hole until the flattened anterior tip was nearly flush with the inner surface of the polyester cell lining. The lateral edges of the cut host cell lining surrounding the neck region and the flattened anterior tip of the Epeolus egg were then firmly melded to those sections of the egg chorion (Fig. 1, 3, and 5-8). As a result, only the flattened, anterior tip of each $E$. compactus egg was attached to the host cell (Fig. 9 ), whereas that section of the egg posteriad of the neck was found hanging in an open space at a point outside the host cell (Fig. 10).

Although egg deposition was not directly observed, the data indicate how E. compactus deposited each egg. The female entered an unprovisioned or partially provisioned cell and exserted metasomal sternum VI through the apical tip of the abdomen. She then used the paired, spined projections of that sternum to cut or punch through the polyester lining to produce a U-shaped hole with a flap of cell lining attached (Fig. 5 and 9). Egg deposition was completed as the female Epeolus controlled the passage of the egg from her ovi- 

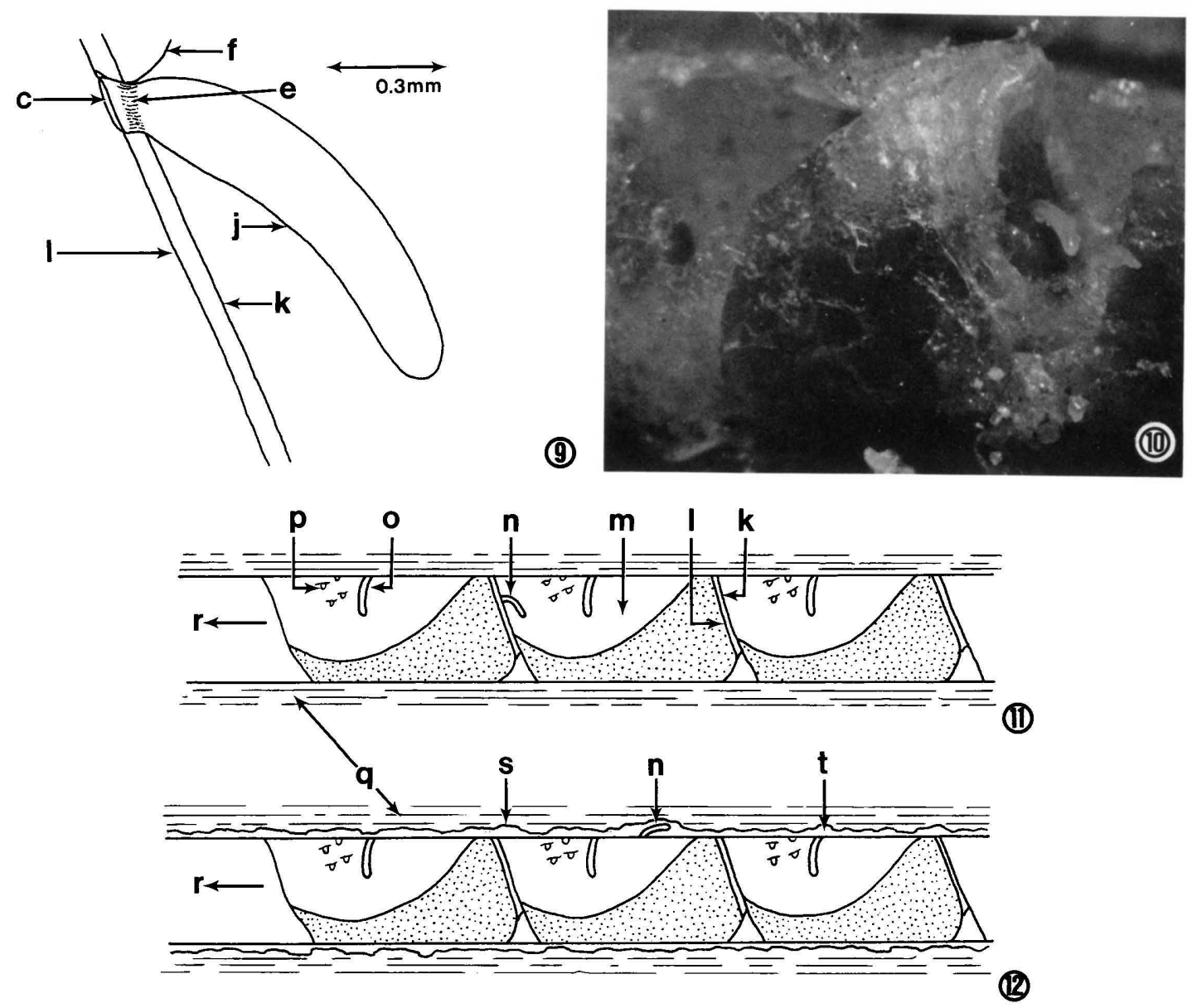

Fig. 9-12. E. compactus. (9) Schematic diagram of egg deposited through cell cap of next lower host cell in linear series, demonstrating how the angulation of the flattened anterior tip of egg influences egg positioning when the anterior tip is flush or nearly flush with the angled host cell cap. (10) Photograph of egg deposited through cell cap of host species. (11) Schematic diagram in longitudinal view of linear series of C. kincaidii cells constructed in burrow excavated by a foundress female (the egg of $E$. compactus is attached to the cell cap of the middle cell but the first instar will emerge into the outermost cell). (12) Diagram of a second series of host cells constructed within residue cell linings in an abandoned burrow. Note that the E. compactus egg is deposited through the side wall of the same cell parasitized and that the egg is inserted in the open space between the lining of cell parasitized and residue cell lining produced by previous generations. (c, operculum; e, part of cell lining layer melded to egg; $\mathrm{f}$, a flap of host cell lining that is pushed inward during period that parasite cuts hole through a section of polyester lining preparatory to egg deposition; $\mathbf{j}$, dorsal surface of $\boldsymbol{E}$. compactus egg; $\mathbf{k}$, inner surface of cell cap; 1 , outer surface of basal section of host cell lining; $\mathrm{m}$, open space in host cell; $\mathrm{n}, E$. compactus egg (ventral surface); $o, C$. kincaidii egg; p, droplets of Dufour's gland liquid; q, soil; r, direction of nest entrance; s, edge of residue cell lining produced by previous generations of host females; $t$, narrow open space between cell series constructed in existing host burrows and residue cell linings that were constructed by previous generations.)

duct opening and into the hole cut in the host cell lining.

As the egg was deposited, a small quantity of liquid secretion (probably Dufour's gland material) was applied onto the neck region of the Epeolus egg. This secretion dissolved the cut edges of polyester cell lining, and the resultant liquid filled the space between the neck region of the deposited egg and the host cell lining. The liquid then solidified to form a continuous hygrophobic polyester layer that melded and tightly sealed the anterior section of the Epeolus egg (neck region and anterior tip) to the host cell lining (Fig. 9 and 10).

Oviposition by E. compactus was restricted to two areas of the host cell, either through the upper side wall of an open cell or through the cap of a completed cell abutting against the basal surface of an open cell. These oviposition sites were associated directly with both types of nest architectural designs found in the two C. kincaidii nesting populations studied at Bonny Doon (Torchio et al. 1988). As a consequence, E. compactus used the cell cap 
Table 1. Numbers of nests and cells of $C$. kincaidii constructed at two nests sites

\begin{tabular}{|c|c|c|c|c|}
\hline Nest site $^{a}$ & $\begin{array}{l}\text { No. } \\
\text { nests }\end{array}$ & $\begin{array}{l}\text { No. } \\
\text { cells }\end{array}$ & $\begin{array}{l}\text { No. cells with } \\
\text { E. compactus }\end{array}$ & $\begin{array}{c}\text { No. old } \\
\text { nests not } \\
\text { used } \\
(1985)\end{array}$ \\
\hline \multicolumn{5}{|c|}{ Host cells in burrows excavated by nesting females } \\
\hline 1 & 5 & 44 & 0 & - \\
\hline 2 & 24 & 216 & 21 & - \\
\hline Subtotal & 29 & 260 & $21(8.1 \%)$ & \\
\hline \multicolumn{5}{|c|}{ Host cells in nests excavated by previous generation } \\
\hline 1 & 1 & 2 & 1 & 6 \\
\hline 2 & 16 & 78 & 25 & 56 \\
\hline Subtotal & 17 & 80 & $26(32.5 \%)$ & 62 \\
\hline Total & 46 & 340 & $47(13.8 \%)$ & 62 \\
\hline
\end{tabular}

${ }^{a}$ Nest site 1 excavated March 1985; nest site 2 excavated July 1985.

${ }^{b}$ Rates of parasitism by E. compactus based on numbers of host cells constructed by the same females that excavated entire nes burrow versus other females that constructed cells in nests excavated by previous generations.

oviposition site whenever a host female excavated her own burrow system and constructed linear series of cells in those burrows (Fig. 11). Alternatively, the upper side-wall oviposition site was used by $E$. compactus when the host female constructed linear series of horizontal cells within residue cell linings in old burrows excavated by females of previous generations (Fig. 12) (Torchio et al. 1988).

The rate of parasitism by $E$. compactus was higher in those $C$. kincaidii cells constructed within residue cell linings of abandoned nests excavated by previous generations (32.5\%) than in cells constructed in burrows excavated by the same nesting female $(8.1 \%)$ (Table 1). These data suggest that parasitism by E. compactus was greater at the larger nest site (Table 1; site 2), which had larger numbers of nesting females and old nests available for reuse, versus the more recently established site (site 1), which had fewer numbers of old nests and foundress females excavating new burrows. Yet, the proportionate number of nesting females that excavated their own burrows at both sites ( 5 at site 1,24 at site 2) was higher than the number of females that reused old nests at these same nest sites ( 1 at site 1,16 at site 2 ). irrespective of total numbers of old nests that could have been reused (6 at site $1 ; 72$ at site 2 ) (Table 1 ).

Multiple parasitism (two and three E. compactus eggs per cell) occurred in both reused and excavated host nests at site 2 . Of the 26 cells parasitized in reused nests (Table 1), 5 cells each had two $E$. compactus eggs and 3 cells each had three Epeolus eggs. All of these eggs were deposited through the side walls of $C$. kincaidii cells. Of the 21 cells parasitized in excavated nests, three cells each had two Epeolus eggs and one cell had three $E$. compactus eggs. All of these eggs were inserted through the cell cap of the previous cell in the series. However, we could not determine if one E. compactus female deposited two or three eggs in these host cells or if each egg was deposited by a different female.

The association between choices of oviposition sites by $E$. compactus and types of nest burrows used by $C$. kincaidii is primarily a reflection of the adaptive potential expressed by E. compactus. Thus, Epeolus eggs are deposited through the upper side wall of host cells constructed within residue cell linings of old nests, or these eggs are deposited through the cell caps of previously constructed cells when cell series are constructed in burrows excavated by the nesting female. The functional basis for this adaptive potential is outlined as follows:

(1) It is known that a closely related genus, Triepeolus, has a pair of very long projections on metasomal sternum VI (Fig. 13) which are used to excavate holes in the soil walls of host cells (Anthophora and Eucerini) into which the straight, unbent eggs are inserted (Torchio 1986). Epeolus has much shorter projections associated with metasomal sternum VI (Fig. 14), and these inwardly angled structures are ornamented with toothlike spines (Fig. 15) that are used to cut holes through the polyester cell linings of Colletes host cells.

(2) When C. kincaidii constructs its cell series in freshly excavated burrows, it deposits its cell lining directly onto the soil surface of the burrow. Unlike the double-layered and single cell-lateral burrow constructed by C. ciliatoides (Torchio 1965) and C. compactus compactus (Rozen \& Favreau 1968), there is little or no space between the one-layered cell wall lining and soil walls of cell series constructed by $C$. kincaidii.

(3) As a consequence, the only open space adjacent to these cells that is large enough to accommodate inserted Epeolus eggs is the air space within each previously constructed cell in the series (Fig. 11).

(4) To use this space, the strongly curved $E$. compactus egg is inserted through the basal section of the open cell to be parasitized and through the cell cap of the previously constructed cell (Fig. 9 and 10). This is accomplished as the egg-laying female is positioned with her venter facing the outer surface of that cell cap into which the Epeolus egg is inserted, and her head is directed toward or onto the dorsal surface within the horizontal cell (Fig. 17). This orientation assures that each E.compactus egg is deposited with its posterior tip facing the ventral surface of the horizontal cell and its dorsum facing the inner surface of the cell cap (Fig. 9). As a result, the flattened but slanted anterior tip of a deposited Epeolus egg is flush with the basal section of cell lining in the open cell, and the posterior section of the egg behind the neck region is extended into the open space of the previously completed cell in the series (Fig. 9-11). Because of a combination of factors (angled cell cap of host cell, slanted anterior tip of parasite's egg, and the recurvature of its dorsal surface [Fig. $9]$ ), the posterior, free-hanging section of the $E$. 

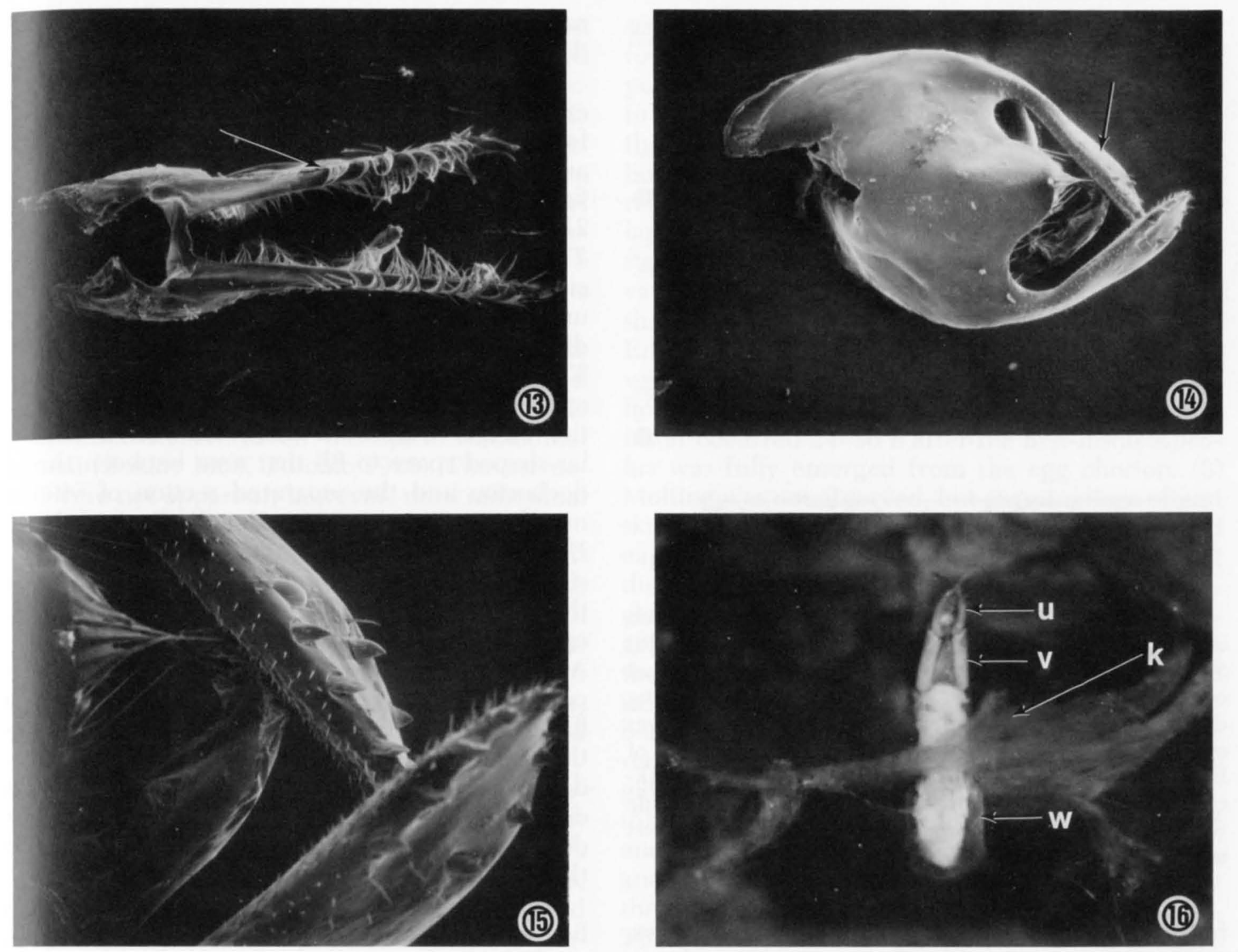

Fig. 13-16. (13) Ventral view of metasomal sternum VI of Triepeolus dacotensis (arrow pointing to pair of long projections used to excavate holes in soil walls of host cells in which eggs are deposited). (14) Ventral view of metasomal sternum VI of $E$. compactus (arrow pointing to pair of host projections used to cut holes in polyester cell linings produced by host bees). (15) Magnified view of projections on metasomal sternum VI of E. compactus showing ornamentation of subapical spines positioned to increase the cutting edges of these projections when they are used to slice host cell linings. (16) First-instar larva of E. compactus during eclosion from the egg attached to cell cap of host cell. ( $k$, inner surface of cell cap; $u$, mandibles of first-instar larva; $v$, head capsule of first-instar larva; w, egg chorion.)

compactus egg somewhat parallels the inner surface of the host's cell cap to which it is attached.

(5) The C. kincaidii females that reuse nests excavated by previous generations construct cells that are very loosely attached to the residue cell linings produced by previous generations.

(6) As a result, numerous but narrow spaces are invariably available between the upper lateral margins of freshly constructed cells and the residue cell linings constructed by previous generations. Although these interstices are narrow, the strong anterior curvature of the Epeolus egg simplifies its insertion into these spaces (Fig. 12). How the female E. compactus recognizes these air spaces adjacent to cells from its position within the open cell is unknown.

(7) The female E. compactus faces the cell opening as eggs are deposited through the upper side walls of host cells (Fig. 18). This allows the curved
Epeolus egg to closely parallel the host cell lining within the narrowed air space between old and new cell linings as it is deposited (Fig. 18). In addition, the egg is oriented with its rounded posterior tip directed toward the basal section of the host cell and its dorsum facing the outer cell lining of the parasitized cell (Fig. 12 and 18).

Late Embryogenesis. Continuous observations of embryo development were not made because most of the Epeolus material died during and soon after transfer to the laboratory. Live material, however, was observed periodically throughout the excavation period and during its transfer. These observations, combined with subsequent examinations of all preserved material ( 28 individuals in picrol formal), demonstrated that late embryogenesis of Epeolus paralleled developmental patterns described earlier for Triepeolus (Torchio 1986).

Late embryogenesis by E. compactus therefore, 

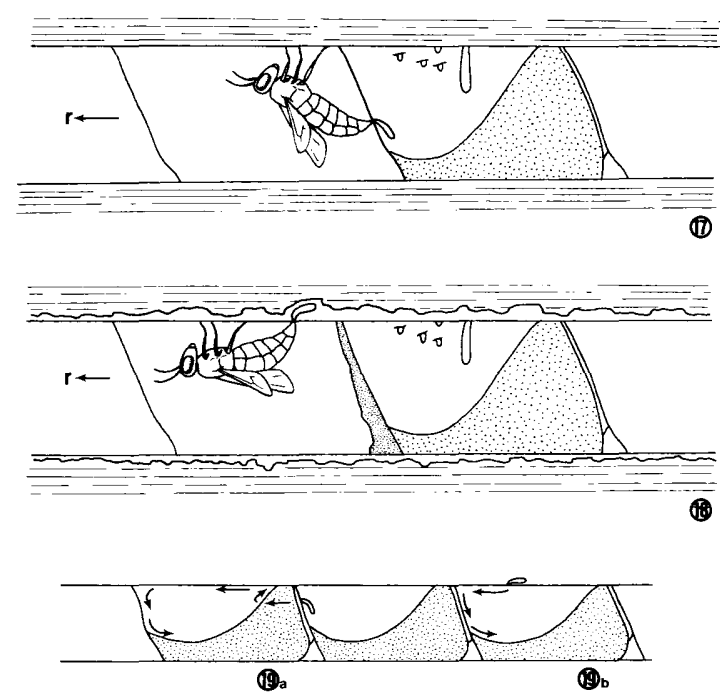

Fig. 17-19. E. compactus. (17) Diagrammatic sketch of female depositing egg through cap of host cell. (18) Sketch of female depositing egg through side wall of host cell. (19a) Sketch of host cell with arrows indicating directional pathway taken when first-instar larva leaves egg deposited through cap of host cell. (19b) Sketch of host cell with arrows indicating directional pathway taken when first-instar larva leaves egg deposited on side wall of same host cell parasitized. ( $r$, direction of nest entrance.)

followed a sequential pattern outlined as follows: (1) Stage 8 (as defined by DuPraw 1967) embryos were not observed. (2) Head and body segments of the embryo developed during late stage 9 (one observation). During this time, the embryo was oriented with its venter facing the dorsum of the egg and its head capsule was directed toward the flattened, anterior tip of the egg. The embryonic membrane (serosa) was separated from the egg chorion around the head region of the embryo, but the characteristic lipidlike microdroplets found floating in embryonic fluid of Triepeolus eggs (Torchio 1986) were not present in Epeolus. (3) Within $2 \mathrm{~h}$ after stage 9 was recognized, the embryo moved its head capsule backward and into the thorax a short distance. These muscle contractions signaled the beginning of stage 10. (4) Muscle contractions continued for $2.5 \mathrm{~h}$ (one observation) before all body movement stopped and the embryo rotated $180^{\circ}$ on its long axis during a $30-\mathrm{min}$ period. The head capsule then began to color as head and body movements were reinitiated. (5) The embryonic membrane softened and collapsed around the head capsule $1 \mathrm{~h}$ after the embryo rotated. This membrane ruptured within the next $35 \mathrm{~min}$, and its dissolution continued for an additional hour during which time the tracheal system filled with gas. Then the foregut began to undulate in a pumping motion, embryonic fluid flowed through the buccal cavity and into the foregut, the embryo expanded rapidly, and the mandibular condyles became fully darkened just before eclosion.

Eggs of the closely related nomadine genus Triepeolus differed from those of Epeolus in that the former had a large, distinctive flange surrounding an operculum that was half the diameter of the flange and operculum together (Torchio 1986, Fig. 2 ). In addition, the vitelline membrane in each Triepeolus egg arose at the junction of the operculum and the flange, and it angled posteriorly until melding to the endochorion at the minimum diameter of the egg $0.3 \mathrm{~mm}$ from its anterior tip. Thus, the anterior $0.3-\mathrm{mm}$ section of each Triepeolus egg chorion was angled outwardly to meet the flange, which, in turn, allowed a triangular-shaped space to fill that area between the endochorion and the separated section of vitelline membrane (Torchio 1986, Fig. 2). Conversely, the Epeolus egg had a comparatively large operculum surrounded by a narrow flange (Fig. 1 and 3), and the neck region directly behind the flange and operculum was slightly narrowed (Fig. 3 and 9). As a result, the Epeolus egg chorion was nearly parallel-sided directly behind the operculum and flange (not angled outwardly as in Triepeolus), and the vitelline membrane, if separated from the endochorion, would have closely paralleled the endochorion. We have not yet determined to what degree this membrane is separated (if at all) from the endochorion in Epeolus eggs.

Eclosion from Egg. The methods by which the first-instar E. compactus moved out of its egg chorion (three observations) were nearly identical to those practiced by Triepeolus dacotensis (Steven), which are described in detail elsewhere (Torchio 1986). Eclosion by the first-instar Epeolus larva from within the egg chorion was initiated in a somewhat passive manner (body elongation) soon after its head capsule was fully colored and embryonic fluids were consumed. The consumption of these fluids triggered a rapid elongation of the body; this caused the head capsule to be carried forward until the crossed tips of the elongated mandibles on the prognathous head were appressed against the inner surface of the operculum. As body elongation continued, the mandibles were pushed firmly against the operculum with increasing force until that structure began to separate away from its union with the flange. As a result, the head capsule continued its forward passage through the opercular opening until the body was fully elongated. When the head capsule passed through this opening, it pushed the operculum upward to a nearly perpendicular position until the operculum remained adjoined to the flange only along a short, dorsal connection. At that point, the entire head capsule and first body segment were carried forward of the opercular opening and into the host cell (Fig. 16). This position was maintained for 2$3 \mathrm{~h}$ and was terminated when the larva began opening and closing its mandibles repeatedly. 
The final act of emergence was signaled when the larva pulled its terminal body segments inward and anchored those segments a short distance forward on the ventral surface of the egg chorion. Subsequent expansion of these anchored segments cicurred by means of peristalsis which, in turn, caused the entire larva to be thrust forward a short distance. These activities were repeated until the larva was entirely free from the chorion within 5 min after it first began opening and closing its mandibles.

The emerged first-instar E. compactus, like those of the closely related genus Triepeolus, possessed large lateral body tubercles and a pair of reversible prgopodlike structures on the apical abdominal segment (Bohart 1966, Torchio 1986). These structures were not apparent, however, until individual body segments emerged from the egg chorion.

Development of Immatures. Each first-instar $E$. compactus emerging from eggs inserted through the cell cap of the previous cell moved through liquefied provisions of the parasitized host cell, and all of these larvae were oriented with their terga facing the ventral surface of host cells. Upon reaching the surface of cell provisions, the Epeolus larva moved its head capsule until the labiomaxillary section contacted the surface of the host cell provisions. The larva then moved forward (upward) on the surface of the angled section of the host's cell provisions, onto the upper cell wall surface, across the inner surface of the host's cell cap, and finally onto the horizontal surface of host cell provisions that covered the anteroventral section of the host cell (Fig. 19a). Larvae emerging from the side walls of parasitized cells escaped immersion in liquefied provisions, but each of these larvae also moved forward across the upper host cell wall, downward on the inner surface of the cell cap, and onto the surface of the horizontal section of host provisions (Fig. 19b).

First-instar Epeolus larvae used their long, sickleshaped mandibles to destroy any egg or larva (host or sibling) encountered, especially during ambulatory periods (three observations). Only one firstinstar Epeolus in multiparasitized host cells survived combat with other Epeolus first instars. Surviving larvae did not feed on the contents of their immature victims, but they subsequently consumed quantities of host provisions (documented when six individuals were cleared in $10 \%$ potassium hydroxide, revealing pollen grains filling the foregut of each when viewed at $200 \times$ ).

The elongate lateral tubercles on most body segments of the first-instar Epeolus larva did not impede the ambulatory, peristaltic movements of the larva within the host cell. However, these tubercles did act as stabilizers and pontoons when the elongated larva floated and fed on the surface of the liquefied host cell provisions.

One of the three first-instar Epeolus larvae to survive the stresses of interstate transport and sub- sequent manipulations into artificial cells died before molting. In an effort to increase the survival potential of the two remaining larvae, we decided to abandon frequent microscopic examinations of the material in an effort to maintain very high humidities (>97\%) within the artificial cells used as rearing chambers. As a result, both of these Epeolus larvae were successfully reared to the prepupal stage at the expense of obtaining complete observational data. Those data obtained as a result of short, daily observations are outlined as follows: (1) Embryogenesis (from egg deposition to a fully developed embryo) of both Epeolus and its Colletes host required 6-8 d. (2) Molting from first to second instar occurred 24-36 h after the first-instar Epeolus was fully emerged from the egg chorion. (3) Molting was not observed, but examinations of cast skins indicated that the ecdysial line on the head capsule of the first instar splits open at some point during the molting period. (4) The distinctive elongated lateral body tubercles and the eversible pygopodlike structures on the terminal segment of the first instar were not retained on the second instar. Also, the elongated mandibles, labral tubercles, and maxillary palpi of the first instar were reduced in size in the second instar, but the elongated head capsule and body form were retained. (5) The hypognathous head capsule of the third and subsequent instars was rounded (not elongate), and the mandibles, labral tubercles, and especially the maxillary palpi were strongly reduced in size. The latter instars were also turned onto their sides as they fed in a C-shaped position. (6) The last (fifth) instar consumed the remaining host cell provisions before defecating, and feces were spread across most or all of the cell wall surfaces. (7) Within $13 \mathrm{~d}$ after egg eclosion, the postdefecating larva hardened and entered into the overwintering prepupal form without spinning a cocoon. (8) Pupal development occurred after prepupae were exposed to wintering temperatures $\left(2^{\circ} \mathrm{C}\right)$ for a minimum of $90 \mathrm{~d}$ followed by incubation temperature $\left(26^{\circ} \mathrm{C}\right)$ for $26 \mathrm{~d}$. These results suggest that E. compactus is a univoltine species.

\section{Discussion}

Our observations, when combined with available literature on Epeolus biology (Torchio 1965, Rozen \& Favreau 1968) and selected literature on Colletes (Claude-Joseph 1926, Malyshev 1968, Torchio et al. 1988), suggest that Colletes is a soil-nesting genus of bees with representative species (C. ciliatus Friese in South America, C. kincaidii in North America, C. inexpectata Noskiewicz in Europe) having individuals in any nesting population that excavate their own burrow systems in soil and other individuals that use existing holes in which to nest (including nest burrows constructed by previous generations). The biologies of only two Epeolus species are now known-E. pusillus attacks Col- 
letes spp. that excavate their own nest burrows and construct single cells in lateral burrows, and $E$. compactus parasitizes $C$. kincaidii that excavate their own burrows or reuse old burrows constructed by previous generations.

Our results (Table 1) suggest that parasitism by E. compactus is increased in reused C. kincaidii nests in which series of linear cells are constructed within old residue cell linings. In these particular nests, Epeolus restricts its oviposition site to only the upper cell wall of horizontal host cells. This oviposition site allows $E$. compactus access into the host cell as soon as cell-lining activities are completed and throughout the provisioning period when the host female leaves the nest unguarded for lengthy periods. Conversely, E. compactus deposits its egg only through the basal section of host cells constructed in burrows excavated by the same host female. This requires Epeolus to deposit eggs before or very soon after the host bee initiates collections of the pollen-nectar cell provisions that cover the basal sections of each cell. As a consequence, host cells constructed in burrows excavated by the nesting female are individually vulnerable to Epeolus attack for briefer periods of time relative to host cells constructed in burrows excavated by previous generations. In addition, the lowermost cell in any linear series constructed by any $C$. kincaidii female that excavates its own burrow is not vulnerable to Epeolus parasitism (no available open space adjacent to the cell into which an egg can be inserted). This lowermost cell in each linear series contains the female sex in all nests examined (Torchio et al. 1988); therefore, it represents a higher investment in the energetics of the host species (Torchio \& Tepedino 1980).

In this paper we show that more C. kincaidii individuals within a nesting population are foundress females that construct their own burrow systems even when these females nest at older nest sites where numerous burrows excavated by previous generations are available for reuse (Table 1). In another paper (Torchio et al. 1988), we report that approximately the same number of host cells $(27-28)$ can be constructed by any one host female during the course of one flight season irrespective of which of the two nesting habits are practiced (excavating own burrow or nesting in existing holes). Results presented in that paper also demonstrate that the $27-28$ cells constructed by a female using existing holes are completed in more than one nest tunnel (three complete nests), whereas a female that excavates her own tunnel normally produces the same number of cells in two or three lateral burrows within one nest. One data set additionally indicates that nongenetic factors are involved in determining whether a host female excavates her own burrow system or establishes nests in existing holes (individuals reared from cells constructed by a foundress female established nests in existing holes).
These combined data suggest that the two nesting alternatives available to a female of C. kincaidii are adaptively equalized by various factors, including differential parasitism by $E$. compactus. For example, it is obvious that more energy is expended by a female $C$. kincaidii excavating her burrow system in soil before constructing cells than by a female that uses an existing hole in which to construct cell series. However, the probability of parasitism by $E$. compactus in host nests constructed within existing holes is four times greater than the potential rate of parasitism in those nests in which cells are constructed by the same foundress female that excavates de novo nest burrows (Table 1). In addition, all of the cells constructed in an existing cavity are vulnerable to Epeolus attack, whereas the lowermost (female) cell (with higher investment potential) in series constructed in burrows excavated by the same nesting female is exempt from Epeolus parasitism. Conversely, females using existing holes normally complete more than one nest per season, but the female expends additional energy by producing additional polyester to form a false cell in front of each cell series and a nest plug near the nest entrance (these structures are not constructed in nests excavated by foundress females). Increasing the number of nests constructed by any one female does, however, decrease the probability of early orientation by $E$. compactus to a Colletes nest. Once Epeolus orients to an active host nest, she tends to revisit that nest frequently and, as a result, parasitism is increased in that nest (unpublished data).

These interrelated results are important when used to establish the parameters of variation in the nesting behavior of host-parasite species. For example, data obtained on the nesting biology of $C$. kincaidii (Torchio et al. 1988) were used in describing the adaptive potential of a host species. Results obtained on the biology of E. compactus are presented in a comparative format (with those of $C$. kincaidii) to quantify the coadaptive potential of parasite and host species.

The polyester lining of Colletes cells is composed of salivary secretion overlayed with Dufour's gland material that issues forth from the tip of the abdomen in liquid form (Torchio et al. 1988). Direct observations of cell lining construction by C. kincaidii suggests that enzymes are involved in the polymerization of ester components and linkage of esters into the hygrophobic polyester cell linings found in Colletes cells. In this paper we show that E. compactus deposits a liquid during egg deposition that reacts chemically with the polyester cell lining produced by the host bee. This chemical reaction acts to bind the Epeolus egg to the polyester cell lining as resolidification occurs to form a watertight seal around the Epeolus egg. Although we did not determine the origin of this Epeolus secretion, we suspect that the liquid was released during egg deposition and that its origin is Dufour's 
gland or another abdominal gland. Chemical analrses of this secretion would determine whether this material is similar or identical to chemical components found in the polyester cell linings of Colletes cells. These results could then be used to support the hypothesis of chemical coevolution in the Apoidea (Tengö \& Bergström 1976, 1977; Hefetz et al. 1982; Cane 1983).

The genus Epeolus is taxonomically placed in the subfamily Nomadinae within the family Anthophoridae. All nomadine bees are parasites of other bees. Although adults are structurally diverse (13 tribes), they are biologically similar. Females enter open cells of host bees and deposit eggs into or through cell walls; the first instar ecloses from the egg after each host cell is sealed, the ambulatory larva destroys host eggs and young larvae (or rival nomadine larvae) with its sickle-shaped mandibles; and host cell provisions are subsequently consumed. More recently, a number of structural characteristics have been found in studies of apoid eggs (Torchio 1986) and larvae (Rozen 1954, 1966; Michener 1957; Rozen \& Michener 1968; Rozen \& NcGinley 1974).

To compare these characteristics in adequate detail is beyond the scope of this study. However, comparisons of particular structures show patterns of similarities and dissimilarities that do not always parallel deduced evolutionary relationships based on adult systematics. For example, the flange and operculum at or near the flattened anterior tip of many nomadine eggs are unique characteristics in the Apoidea. However, these features characterize the eggs of only some tribes (Ammobatini, Biastini, Epeolini, Protepeolini), but they are absent on eggs of the other known nomadine tribes (Holcopasitini, >omadini) (reviewed by Torchio 1986). Nomadine eggs with flanges and opercula are deposited with their flattened anterior tips flush or nearly flush with the host's cell wall, whereas eggs without these structures have their rounded anterior tips exposed above the cell wall within the air space of the host cell.

Nomadine larvae, especially first-instar larvae, have numerous structures that are found in more than one tribe, or they can vary between genera within particular tribes. The elongated labral tubercles on Epeolus, for example, are also found on other Epeolini (Triepeolus), known Nomadini, Biastini (unpublished data), and Ammobatini, but they are absent on first-instar larvae of Isepeolini and Protepeolini. In some tribes (Epeolini, Nomadini [Nomada]) the elongated maxillary palpi are associated with elongated labral tubercles; in other tribes (Protepeolini, Isepeolini) neither structure is elongated; in another tribe (Biastini [Biastes]) the labral tubercles are elongated but the maxillary palpi are not (unpublished data); and in yet another tribe (Ammobatini), these same characteristics vary at the generic level (Oreopasites with long labral tubercles and short maxillary palpi [Rozen 1954];
Pasites with both elongated labral tubercles and maxillary palpi [Rozen 1986]). Other characteristics include: Eggs-reticulations or annulations or both on the chorion, the shape of and ornamentations on the operculum, the angulation of the flattened anterior tip, size of operculum compared with that of flange, degree of curvature of deposited eggs, and the presence or absence of a neck region; first instar-lateral body tubercles, a bilobed eversible process on the terminal body segment, head and body setae and spicules, body form, and a host of head capsule features. The long, sickle-shaped mandibles of nomadine first-instar larvae appear, however, to be a shared, derived feature of this subfamily.

The comparisons discussed here demonstrate that some nonadult, shared characteristics parallel present nomadine classifications, especially at the tribal level. In at least one tribe, however, the number of nonshared characteristics among known genera are as numerous as among tribes. For example, comparative studies of egg structure and first-instar larvae show that there are at least as many shared characteristics when Epeolini and the ammobatine genus Pseudodichroa are compared as when Pseudodichroa and another ammobatine genus (Oreopasites) are compared. These results suggest that the present classification of nomadine genera and tribes may not reflect accurately the phylogenetic relationships of all nomadine taxa. These comparative data, while incomplete, indicate that nonadult characteristics may prove enlightening for use in phylogenetic studies (Torchio 1986); therefore, they should be included in future biosystematic studies of the Nomadinae.

\section{Acknowledgment}

Our sincerest appreciation is extended to Mrs. Ella Alluisi, who allowed us access onto her Bonny Doon property, directed us to a number of isolated nesting sites, and permitted the removal of nesting blocks. Andy Moldenke (Oregon State University, Corvallis) directed us to the field site and made available an unpublished manuscript. Glen Trostle (USDA-ARS, Bee Biology Laboratory, Logan, Utah) shared in some of the laboratory observations, and Ellen Parker (Logan, Utah) inked the figures. Bill McManus (Utah State University, Logan) is responsible for the electron microscope photographs. Richard Rust (University of Nevada, Reno), Jan Tengö (Uppsala University, Sweden), Jim Cane (Auburn University, Auburn, Ala.) and Michael Johnson (DePauw University, Greencastle, Ind.) reviewed the manuscript. This is a contribution from the Utah Agricultural Experiment Station, Utah State University, Logan, Journal Paper No. 3438, and USDA-ARS, Bee Biology and Systematics Laboratory, Utah State University, Logan.

\section{References Cited}

Bohart, G. E. 1966. Notes on Triepeolus remigatus (Fabricius), a "cuckoo bee" parasite of the squash bee, Xenoglossa strenua (Cresson). Pan-Pac. Entomol. 42: 255 262. 
Brumley, R. L. 1965. A revision of the bee genus Epeolus Latreille of western America north of Mexico. M.S. thesis, Utah State University, Logan.

Cane, J. H. 1983. Olfactory evaluation of Andrena host nest suitability by kleptoparasitic Nomada bees (Hymenoptera: Apoidea). Anim. Behav. 31: 138-144.

Claude-Joseph, F. 1926. Recherches biologiques sur les Hyménoptères du Chile (Mellifères). Ann. Sci. Nat. Zool. Biol. Anim. (10) 9: 113-268.

DuPraw, E. J. 1967. The honey bee embryo, pp. 183217. In F. H. Wilt \& N. K. Wessels [eds.], Methods in developmental biology. Crowell, New York.

Hefetz, A., G. C. Eickwort, M. S. Blum, J. Cane \& G. E. Bohart. 1982. A comparative study of the exocrine products of cleptoparasitic bees (Holcopasites) and their hosts (Calliopsis) (Hymenoptera: Anthophoridae, Andrenidae). J. Chem. Ecol. 8: 1389-1397.

Krombein, K. V., P. D. Hurd, D. R. Smith \& B. D. Burks [eds.]. 1979. Catalog of Hymenoptera in America north of Mexico, vol. 2. Smithsonian Institution, Washington.

Malyshev, S. I. 1968. Genesis of the Hymenoptera. Methuen, London.

Michener, C. D. 1957. Notes on the biology of a parasitic bee, Isepeolus viperinus (Hymenoptera, Anthophorinae). Entomol. News 68: 141-146.

Rozen, J. G., Jr. 1954. Morphological description of the larva of Oreopasites vanduzeei Cockerell. PanPac. Entomol. 30: 203-207.

1966. The larvae of the Anthophoridae (Hymenoptera: Apoidea). Part 2. The Nomadinae. Am. Mus. Novit. 2244: 1-38

1986. The natural history of the Old World nomadine parasitic bee, Pasites maculatus (Anthophoridae: Nomadinae), and its host, Pseudapis diversipes (Halictidae: Nomiinae). Am. Mus. Novit. 2861: 1-8.

Rozen, J. G., Jr., \& M. S. Favreau. 1968. Biological notes on Colletes compactus compactus and its cuck- oo bee, Epeolus pusillus (Hymenoptera: Colletidae and Anthophoridae). J. N.Y. Entomol. Soc. 76: 106111

Rozen, J. G., Jr., \& R. J. McGinley. 1974. Systematics of ammobatine bees based on their mature larvae and pupae (Hymenoptera, Anthophoridae, Nomadinae). Am. Mus. Novit. 2551: 1-16.

Rozen, J. G., Jr., \& C. D. Michener. 1968. The biology of Scrapter and its cuckoo bee, Pseudodichroa ( $\mathrm{Hy}$ menoptera: Colletidae and Anthophoridae). Am. Mus. Novit. 2335: 1-12.

Tengö, J. \& G. Bergström. 1976. Odor correspondence between Melitta females and males of their nest parasite Nomada flavopicta (Hymenoptera: Apoidea). J. Chem. Ecol. 2: 57-65.

1977. Cleptoparasitism and odor mimetism in bees: Do Nomada males imitate the odor of Andrena females? Science 196: 1117-1119.

Torchio, P. F. 1965. Observations on the biology of Colletes ciliatoides (Hymenoptera: Apoidea, Colletidae). J. Kans. Entomol. Soc. 38: 182-187.

1986. Late embryogenesis and egg eclosion in Triepeolus and Anthophora with a prospectus of nomadine classification (Hymenoptera: Anthophoridae). Ann. Entomol. Soc. Am. 79: 588-596.

Torchio, P. F., G. E. Trostle \& D. J. Burdick. 1988. The nesting biology of Colletes kincaidii Cockerell (Hymenoptera: Colletidae) and development of its immature forms. Ann. Entomol. Soc. Am. 81: 605625.

Torchio, P. F. \& V. J. Tepedino. 1980. Sex ratio, body size and seasonality in a solitary bee, Osmia lignaria propinqua Cresson (Hymenoptera: Megachilidae). Evolution 34: 993-1003.

Received for publication 14 August 1987; accepted 8 March 1988. 